Proceedings

\title{
Digital Tools as an Enabler for Educational and Training Processes: The Case Study of REFUGEEClassAssistance4 Teachers Project ${ }^{+}$
}

\author{
Ourania Areta ${ }^{1, *}$ and Karel Van Isacker ${ }^{2}$
}

1 Izmir Bakircay University, Izmir 35665, Turkey

2 PhoenixKM BVBA, 8610 Kortemark, Belgium; karel@phoenixkm.eu

* Correspondence: ourania.areta@bakırcay.edu.tr

+ Presented at the 7th International Management Information Systems Conference, Online, 9-11 December 2020.

Citation: Areta, O.; Isacker, K.V. Digital Tools as an Enabler for Educational and Training Processes: The Case Study of REFUGEEClass Assistance4Teachers Project. Proceedings 2021, 74, 14. https://doi.org/ 10.3390/proceedings2021074014

Published: 12 March 2021

Publisher's Note: MDPI stays neutral with regard to jurisdictional claims in published maps and institutional affiliations.

Copyright: $(2021$ by the authors. Licensee MDPI, Basel, Switzerland. This article is an open access article distributed under the terms and conditions of the Creative Commons Attribution (CC BY) license (http://creativecommons.org/licenses/by/4.0/).

\begin{abstract}
Digitalization has transformed all aspects of life, from social interactions to the working environment and education, something that accelerated with the emergence of COVID-19. The same stands for education and training activities, where the use of digital tools has been gradually advancing and become merely online because of the virus. This brought forth the need to discuss further the applications, benefits, and challenges of digital tools within the framework of the education and training process, and the need to study examples of successful applications. This study aims to support both these requirements by presenting the case study of REFUGEEClassAssistance4Teachers project and its outcomes.
\end{abstract}

Keywords: digital tools; training; project; case study

\section{Introduction}

Digitalization has transformed all aspects of life, from social interactions to the working environment and education [1]. This digital transformation went along with all Information and Communications Technology (ICT) developments and accelerated because of the COVID-19 outbreak [2]. Within the framework of educational and training processes, the incorporation of technology is not something new, but the pace of Information Technology (IT) advancements and the development of disruptive technologies has left education and training related actors to react and adopt them once they have been applied to other industries first [1].

Even when applied, the use of digital tools for education and training has received mixed reviews from the involved parties (educators and students). That element underlines its potential benefits and disadvantages, as well as the need to study examples of applied digital tools for education and training purposes so that we can get feedback from users and improve processes [3-6]. Moreover, the sudden changes and disruption that COVID-19 brought to the educational and training system at the global level, stress the need to further discuss the involved barriers to overcome and which methodologies to implement [7].

This study will initially present a brief literature review of the associated terminology. Then, the authors will present the digital tools that were developed, tested, and reviewed within the framework of the European Union (KA2-Cooperation for Innovation and the Exchange of Good Practices, Strategic Partnership for School Education) project, named as "Training for teachers how to cope with refugee children in their class" (REFUGEEClassAssistance4Teachers). The specific project was chosen as a case study for successful digital tools implementation within education and training purposes. 


\section{Literature Review}

According to scholars, there is a need to define the terms digitization, digitalization, and digital transformation since they are used interchangeably $[1,8]$. Legner and his colleagues have adopted the following definitions:

- Digitization: "the technical process of converting data and information from analogue into digital formats, meaning adoption and usage of binary digits";

- Digitalization: "the processes of transition toward non-physical information storage, transmission, and processing by using digital technologies";

- Digital transformation: "comprehensive applications of digital technologies in all facets of society to improve and extend products and services, and the creation of new digital alternatives" [8] (p. 301).

However, the integration of ICT in educational and training environments has evolved through the years and has affected the nature of the teaching and learning environment and its description, as shown in Table 1 (based on the work in Reference [1]):

Table 1. Terms used to describe educational and training environments based on technological (use of ICT) and geographical (distance from the location of instruction) characteristics.

\begin{tabular}{cc}
\hline Term & Description \\
\hline e-Learning & broadly defined as almost any activity making use of ICT \\
\hline Online Learning & $\begin{array}{r}\text { part of distance learning; also used as a general term for educational environments using ICT, } \\
\text { computers, and the Internet; learner is at a distance from the tutor or instructor }\end{array}$ \\
\hline Blended Learning & use of both online and face-to-face instruction \\
\hline Mobile Learning & any form of learning through the use of a mobile device \\
\hline
\end{tabular}

A few of the tools that can be used for this learning process are, namely, Online training platforms; Webinars (e.g., Zoom webinar, GoToWebinar); Video-streaming (e.g., YouTube); Web-based text processors (e.g., Google Docs, Microsoft Sharepoint); Webbased project organization and communication tools (e.g., Microsoft Teams); Applications (Apps); Augmented and Virtual Reality; Videogames; Cloud Storage; Digital libraries, etc. $[9,10]$.

From the students' perspective, and especially the generation of the millennials that was born into technological advancements, the incorporation of a few of these aforementioned tools for educational purposes has come smoothly, while the educators struggle more. Overall, the integration of these digital tools into the educational and training processes has gained mixed reviews ([5,9]). Something that the emergency of COVID-19 has stretched even more since it put many countries and their educational systems into a forceful transition from face-to-face to $100 \%$ online status. Based on the literature review, Table 2 summarizes the main benefits and disadvantages that are derived from the usage of digital means:

Table 2. Benefits and disadvantages of digital tools ([1,5,6,9-12]).

\begin{tabular}{cc}
\hline Benefits & Disadvantages \\
\hline Enabling students to collaborate more effectively & Exclusion because of access to IT infrastructure \\
\hline Inclusivity of academic exchanges & Low interaction (e.g., hard to engage in informal talks) \\
\hline Reduction of the time and costs of organizing sessions & Low student engagement/high level of dropout \\
\hline Saving of resources & Result in higher stress levels and reduced personal well-being \\
\hline $\begin{array}{c}\text { Enabling more diverse working environment (geo- } \\
\text { graphical and time flexibility) }\end{array}$ & Low digital competence of educators \\
\hline
\end{tabular}

As far as the methodology that was chosen for this study, the authors decided on the presenting the case study of the REFUGEEClassAssistance4Teachers project and its applied 
outcomes. Regardless of the scientific area, the case study as a research methodology provides researchers with the opportunity to focus on a "case" and maintain a complete and real-world angle [13]. The following section (Section 3) fully describes its framework and the digital tools that were developed and tested during the duration of the project.

\section{Case Study of REFUGEEClassAssistance4Teachers Project}

Twenty-first-century education and teaching practices offer the technical capability to educate via mobile/online technologies and provide education anytime, anywhere [6]. This is exactly what has been embraced by the 3-year REFUGEEClassAssistance4Teachers project, funded by the Erasmus+ KA2-Cooperation for Innovation and the Exchange of Good Practices, Strategic Partnership for School Education program, bringing together refugee, inclusive education, and technology partners from Turkey, Bulgaria, Greece, Serbia, and Belgium. The main aim of the project was to support teachers who were given the delicate task of educating children with a refugee background [14].

Among the more than 3.6 million Syrian refugees registered in Turkey, 21.9\% are children [15]. Similar high percentages are seen also among refugees in European countries. Many of these children have seen the worst possible atrocities during their travels towards safety and have been traumatized. As a result, when they enter the host country's school system, they tend to often isolate and display disruptive behaviour [16].

It is a challenging task for teachers to try to engage with these children, as well as assess their state of mind, and stimulate communication [16]. In order to identify the needs of both the teachers and the students, the consortium of the project undertook an extended survey among the related parties in all partner countries. To facilitate this and meet the derived needs, the project focused on developing digital tools such as mobile Android application, online portal, and educational videos to support the teachers in their interaction with pupils with a refugee background. Overall, digital means have been used by several NGOs and governments that deal with refugee-related issues such as social integration, education and training, funding, seeking of work, communication, etc. [17-20]. This application was piloted in all partner countries, whereby both the teachers and children were invited to participate and engage with each other.

\subsection{The Developed Digital Tools}

\subsubsection{REFUGEEClassAssistance4Teachers Mobile Application}

This app assists teachers in cooperating with their students through a variety of ways:

- Providing access to learning material (training materials, practices, videos, guidelines) for the teacher.

- Access to online forums for teachers to share their experiences.

- Symbol supported communication whereby both the teacher and the pupils can communicate via symbols available in the national partner language (Dutch, Bulgarian, Greek, Turkish, and Arabic), (see Figure 1) based on a bilingual Arabic/English symbol dictionary (Tawasol) (see Figure 2) of frequently used words in spoken and written communication represented by recognizable images and pictograms, relevant to the cultural background of the refugee children. This is especially relevant there where spoken language otherwise would create a barrier.

- Translation support which allows to translate from the national host country language to Arabic, Persian, French, Turkish, Russian, Pashto, and English (see Figure 3).

- The "wheel of emotions" (see Figure 4), as developed by the American psychologist Robert Plutchik (1927-2006), is used to allow children to express their emotions in an attractive and acceptable manner. Using this approach, the children can express different emotions (see Figure 5). 


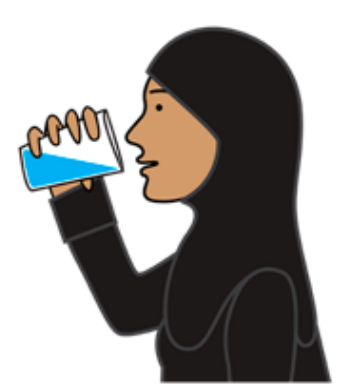

شرَب drink

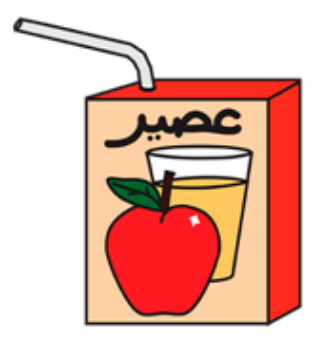

غَصِير juice

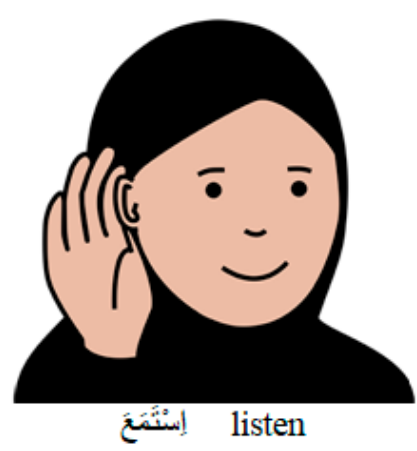

Figure 1. Tawasol symbols and their English/Arabic matching word [21].

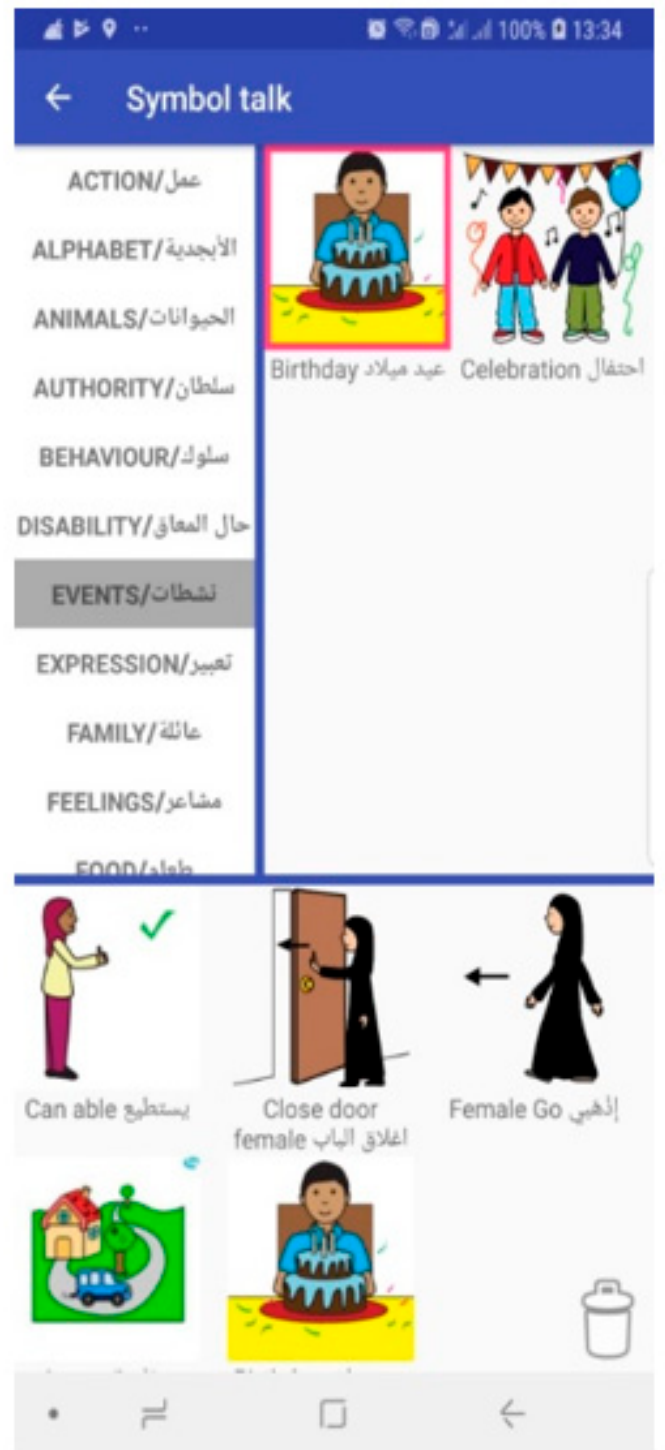

Figure 2. Tawasol symbols used in symbol talk functionality. This example shows how a female refugee child explains that as a girl she is able to leave the house and go to a birthday party [21]. 
$\leftarrow \quad$ Quick Translate

Please enter your text to translate:

[Text to translate

Please select in what language you would like to translate your sentence in

Persian (Iran)

Translated text:

TRANSLATE

Figure 3. Integrated translation functionality [21]. 


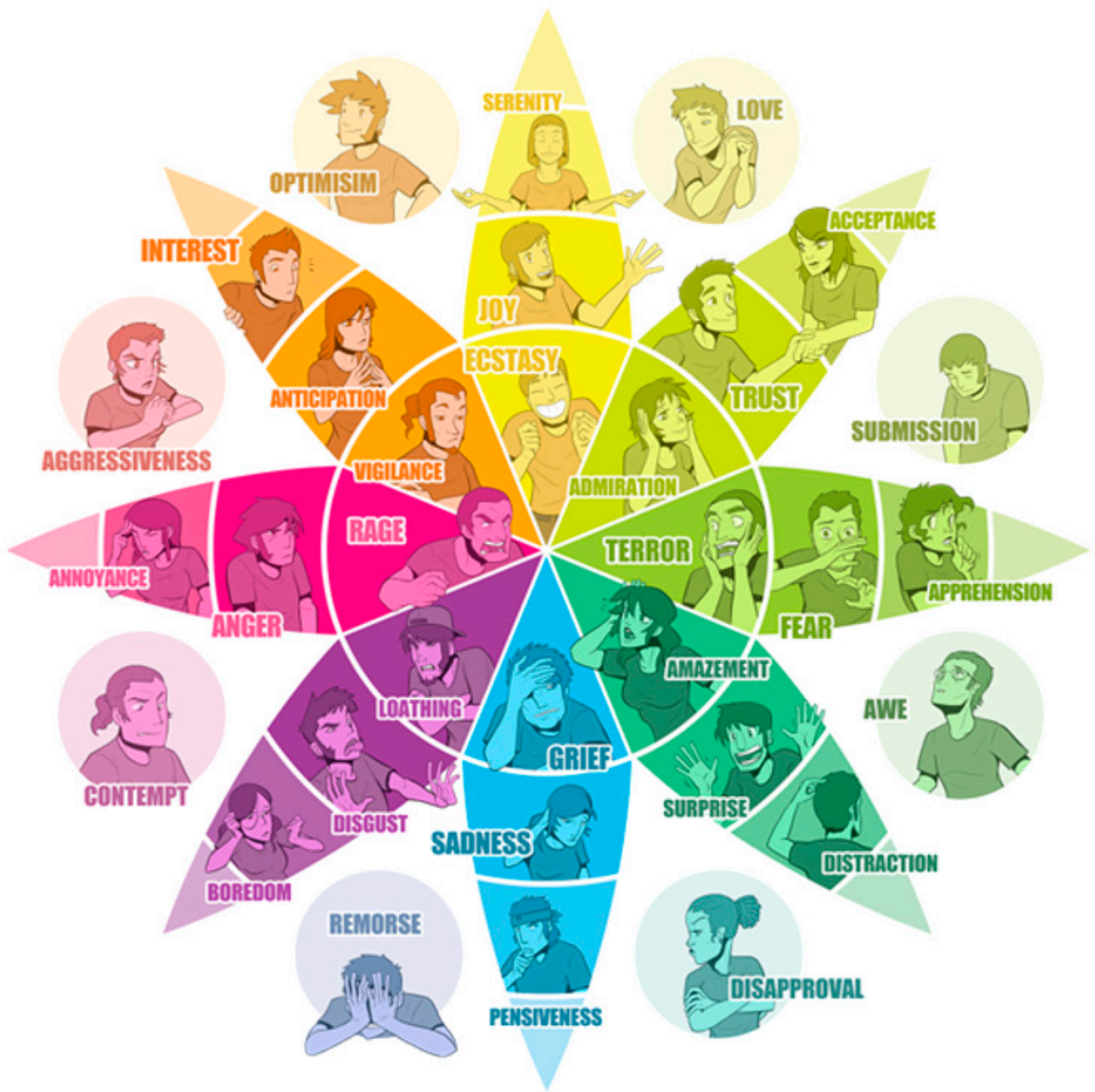

Figure 4. Robert Plutchik's "wheel of emotions" [22].
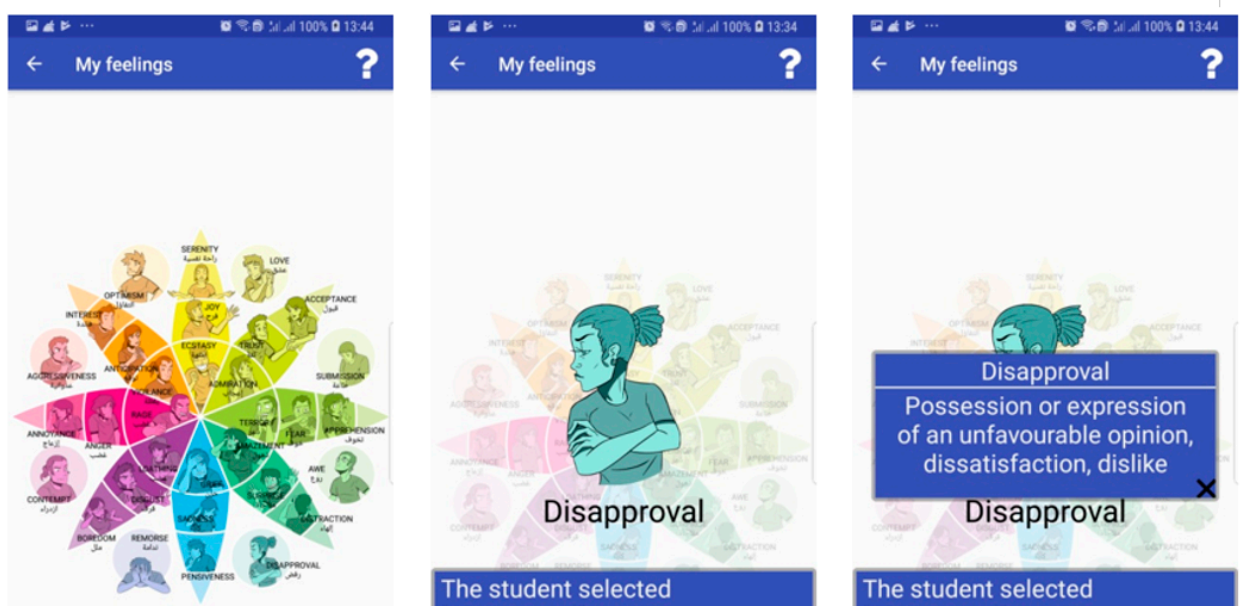

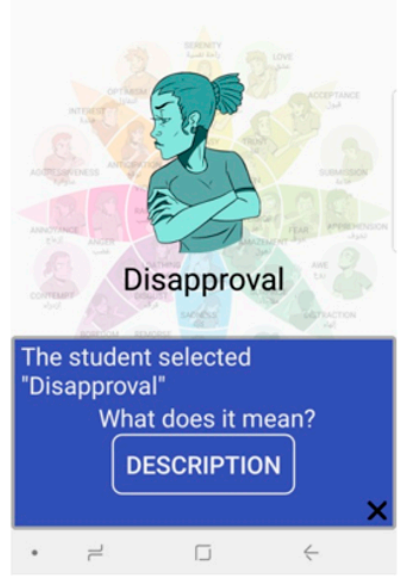

(b)

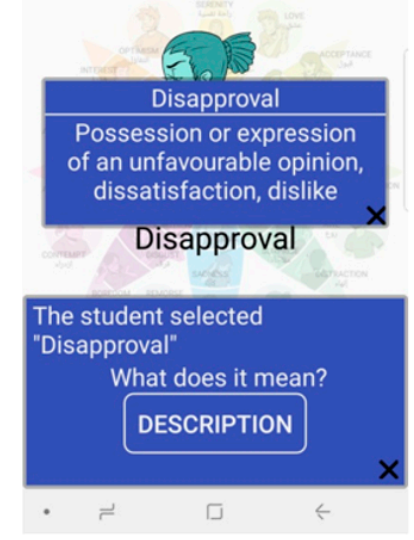

(c)

Figure 5. Robert Plutchik's "wheel of emotions" as applied in project's mobile application: (a) Select the feeling, (b) Receive short clarification of what was selected, (c) Obtain explanation about the selected feeling [21]. 


\subsubsection{REFUGEEClassAssistance4Teachers Portal}

The peer support portal (see Figure 6) was developed for teachers who have children with refugee backgrounds in their classrooms. The multilingual portal offers peer support where teachers can ask for help, offer support, schedule support meetings, and establish focus groups. The portal also offers resources in the following areas: socio-cultural, psychological, and physical development, rights to train refugees, basic language/communication training, good practices across Europe, supports video movies, and guidelines for schools.

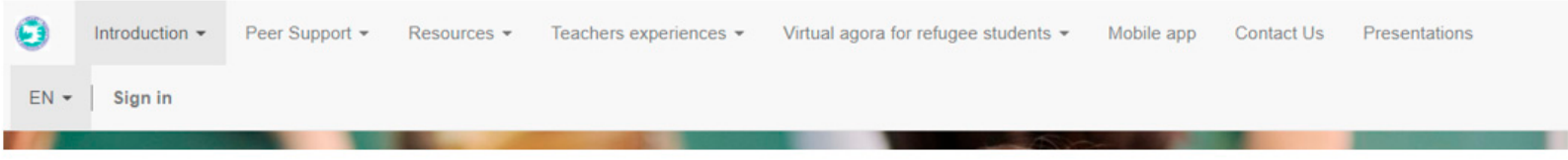

Figure 6. Interface of REFUGEEClassAssistance4Teachers portal [21].

\subsubsection{Videos}

Supporting educative animated videos for a range of scenarios were created (see Figure 7). They are linked to key areas that teachers need to be taught so that they can strengthen the refugee pupil engagement, and were created, based on real cases in each partner country:

- $\quad$ welcome process

- mental health of teachers working with refugee children

- $\quad$ social, cultural, and religious aspects in a diverse society

- communication and language teaching

- mental and physical health of refugee children

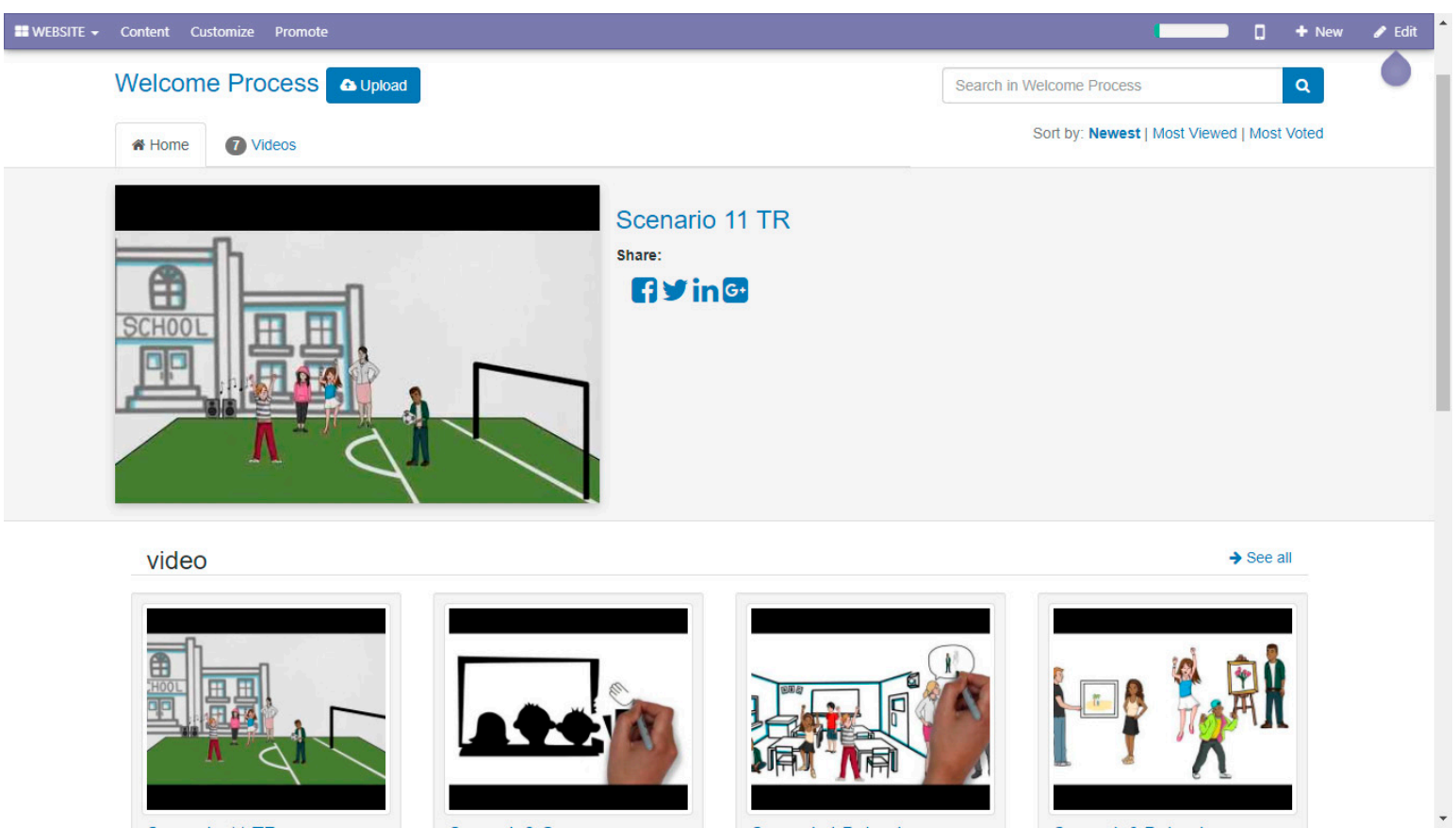

Figure 7. Screenshot of welcome process supporting video [21].

\subsection{Piloting Process Feedback}

The piloting was organized in Turkey, Bulgaria, Belgium, and Greece and reached 306 teachers in various schools where children with a refugee background follow lessons. Apart from using the various tools with the target group, they also provided their feed- 
back afterward, which confirmed the usefulness of the created tools and their daily applicability. The majority of the participants were very satisfied with the content, with emphasis on the Videos and the Mobile Application.

Because all outcomes have been made freely available via http://www.teachers4refugees.eu/, third parties can build further on these materials and adapt them to their own country's situation and needs.

\section{Conclusions}

This study focused on the use of digital means for educational and training purposes, presented its background and the case of the accomplished European Union project "Training for teachers how to cope with refugee children in their class" as a best case study example for the development of digital means that serve the needs of the target group within the framework of training and education purpose. The choice of the specific project was built primarily on its innovative character with developing these types of tools for teachers and refugee children, and on the fact that ahead of designing their specifications, the project took into consideration the explicit needs of the end users, something that should work as a parameter when approaching the specific topic.

Digital tools may be the source of both benefits and challenges, but the era of COVID19 revealed the need for a more structured and mature approach towards their integration into education and training and the study of other successful applied methods.

Author Contributions: All authors made equal contributions in the preparation and writing of the article. All authors have read and agreed to the published version of the manuscript.

Funding: This research received no external funding

Acknowledgments: This study would not have been possible without the support of the "Training for teachers how to cope with refugee children in their class" project, which was funded by the EU, Erasmus+KA2-Cooperation for Innovation and the Exchange of Good Practices, Strategic Partnership for School Education call-Turkish National Agency, and its consortium, namely, Ankara Yildirim Beyazit University, Ankara Milli Egitim Mudurlugu, Directorate General of Migration Management (Goc Idaresi Genel Mudurlugu), Sofia University St. Kliment Ohridski, National Association Of Professionals Working With People With Disabilities (NARHU), PhoenixKM BVBA, N.G.O. CIVIS Plus, SoftQNR.

Conflicts of Interest: The authors declare no conflict of interest.

\section{References}

1. Schmutte, A.M.; Graf, N.; Rascher, S. Führen und Managen in der Digitalen Transformation; Springer Gabler: Wiesbaden, Germany, 2020.

2. Savić, D. COVID-19 and work from home: Digital transformation of the workforce. Grey J. 2020, 16, 101-104.

3. EPALE-Electronic Platform for Adult Learning in Europe. The Rise of Online Learning: The Benefits and Challenges for Teachers-Part Two: Challenges. 2019. Available online: https://epale.ec.europa.eu/en/blog/rise-online-learning-benefits-and-challenges-teachers-part-two-challenges (accessed 11 September 2020).

4. EPALE-Electronic Platform for Adult Learning in Europe. The Rise of Online Learning: The Benefits and Challenges for Teachers-Part One: Benefits. 2019. Available online: https:/epale.ec.europa.eu/en/blog/rise-online-learning-benefits-and-challenges-teachers-part-one-benefits (accessed 11 September 2020).

5. Hillmayr, D.; Ziernwald, L.; Reinhold, F.; Hofer, S.I.; Reiss, K.M. The potential of digital tools to enhance mathematics and science learning in secondary schools: A context-specific meta-analysis. Comput. Educ. 2020, 153, 103897, doi:10.1016/j.compedu.2020.103897.

6. Liesa-Orús, M.; Latorre-Cosculluela, C.; Vázquez-Toledo, S.; Sierra-Sánchez, V. The technological challenge facing higher education professors: Perceptions of ICT tools for developing 21st Century skills. Sustaintion 2020, 12, 5339. doi:10.3390/su12135339.

7. EPALE. Resource Kit \#3-Adult Education in the Post COVID-19 Era. 2020. Available online: https://epale.ec.europa.eu/sites/default/files/resource_kit_03_0.pdf (accessed 15 September 2020).

8. Legner, C.; Eymann, T.; Hess, T.; Matt, C.; Böhmann, T.; Drews, P.; Ahlemann, F. Digitalization: Opportunity and Challenge for the Business and Information Systems Engineering Community. Bus. Inf. Syst. Eng. 2017, 59, 301-308, doi:10.1007/s12599-0170484-2. 
9. Marín-Díaz, V.; Riquelme, I.; Cabero-Almenara, J. Uses of ICT tools from the perspective of chilean university teachers. Sustaintion 2020, 12, 6134, doi:10.3390/su12156134.

10. Schwarz, M.; Scherrer, A.; Hohmann, C.; Heiberg, J.; Brugger, A.; Nuñez-Jimenez, A. COVID-19 and the academy: It is time for going digital. Energy Res. Soc. Sci. 2020, 68, 2, doi:10.1016/j.erss.2020.101684.

11. Arrosagaray, M.; González-Peiteado, M.; Pino-Juste, M.; Rodríguez-López, B. A comparative study of Spanish adult students' attitudes to ICT in classroom, blended and distance language learning modes. Comput. Educ. 2019, 134, 31-40, doi:10.1016/j.compedu.2019.01.016.

12. Lemeshchenko-Lagoda, V.; Kryvonos, I.; Kolodii, O. Integration of information and communication technologies into the process of learning the course of English for specific purposes as one of the requirements for sustainable future development. E3S Web Conf. 2020, 166, doi:10.1051/e3sconf/202016610005.

13. Yin, R.K. Case Study Research: Design and Methods, 5th ed.; Sage Publication: Thousand Oaks, CA, USA, 2015.

14. REFUGEEClassAssistance4Teachers. REFUGEEClassAssistance4Teachers Website. 2019. Available online: https://portal.teachers4refugees.eu/page/whatisportal (accessed 11 September 2020).

15. United Nations. Economic and Social Council. In The Oxford Handbook on the United Nations; Oxford University Press: Oxford, UK, 2020; doi:10.1093/oxfordhb/9780199560103.003.0007.

16. REFUGEEClassAssistance4Teachers. Methodological Guidance for School Principals/Headteachers. 2019. Available online: https://portal.teachers4refugees.eu/slides/set-of-guidelines-assessed-against-nationalregional-realities-and-characteristics-90 (accessed 12 September 2020).

17. AbuJarour, S.; AbuJarour, M. Connecting Human Potentials and Opportunities through Technology: A Digital Integration Use Case. In Proceedings of the 24th Pacific Asia Conference on Information Systems (PACIS 2020), Dubai, UAE, 22-24 June 2020; p. 30.

18. Oduntan, O.; Ruthven, I. People and places: Bridging the information gaps in refugee integration. J. Assoc. Inf. Sci. Technol. 2020, doi:10.1002/asi.24366.

19. Patil, A. The role of ICTs in refugee lives. In Proceedings of the Tenth International Conference on Information and Communication Technologies and Development, Ahmedabad, India, 4-7 January 2019; doi:10.1145/3287098.3287144.

20. Turkay, B.; Turkay, S. Understanding Turkish NGOs' digital technology use in helping refugees in Turkey. Conf. Hum. Factors Comput. Syst. Proc. 2019, 1-6, doi:10.1145/3290607.3312984.

21. REFUGEEClassAssistance4Teachers. REFUGEEClassAssistance4Teachers Portal. 2019. Available online: https://portal.teachers4refugees.eu/ (accessed 13 September 2020).

22. CopyPress, Robert Plutchik's ‘Wheel of Emotions'. 2019. Available online: http://www.copypress.com/blog/your-fragile-emotions-illustrated/ (accessed 13 September 2020). 